\title{
Problem historii filozofii. Część druga
}

DOI: http://dx.doi.org/10.12775/RF.2016.010

Tekst stanowi kontynuację rozważań przedstawionych pod takim samym tytułem, których przedmiot stanowiła dyskusja Hansa-Georga Gadamera z jego neokantowskimi nauczycielami. Problem polega na tym, że Gadamer akcentuje niemożliwość historii filozofii rozumianej jako historia problemów, która stanowi poniekąd wyróżnik neokantystów i odwołuje się do historii pojęć. Rzecz nie jest jednak taka prosta, jak mogłoby się wydawać i trzeba wskazać kilka niejasności związanych z podjętą kwestia, aby uzyskać wymaganą jasność.

Po pierwsze, historia filozofii jako historia problemów jest wyróżnikiem neokantyzmu. Zwyczajowo wskazuje się tu na Wilhelma Windelbanda i opublikowany po raz pierwszy w roku 1892 podręcznik Historii filozofii, gdzie czytamy:

Punkt ciężkości położyłem, co wychodzi na jaw już w zewnętrznej formie, na rozwój tego, co w filozoficznym rozważaniu najważniejsze: historię problem ó w i pojęć. Moim głównym zamiarem było rozumienie jej jako nieprzerwanej i wszystko obejmującej całości. Historyczne splątanie różnych toków myślowych, z których powstał nasz pogląd na świat i życie, stanowi najwłaściwszy przedmiot mojej pracy: i jestem przekonany, że to zadanie należy rozwiązać nie dzięki pojęciowej konstrukcji, lecz tylko dzięki wszechstronnemu, nieuprzedzonemu prześledzeniu faktów. Jeśli jednak - zapewne zgodnie z ekonomią przestrzenną - wydaje się przy tym, że stosunkowo większą część poświęcono starożytności, to opiera się to na przekonaniu, że dla historycznego zrozumienia naszego intelektualnego istnienia wykucie pojęć, które duch grecki wydarł temu, co rzeczywiste w przyrodzie i ludzkim 
życiu, jest ważniejsze niż wszystko, co od tego czasu - wyjąwszy filozofię Kantowską - zostało pomyślane ${ }^{1}$.

Ujawnia się tu jednak pewien problem, gdyż wydawać by się mogło, że również rzecznik historii problemów, Nicolai Hartmann, podąża tropem Windelbanda. Fakt przynależności do innej szkoły neokantowskiej nie jest tu rozstrzygający. Raczej większość neokantystów wykorzystuje ideę głoszoną przez Windelbanda, chociaż na przykład ten, któremu do niego najbliżej, a mianowicie Heinrich Rickert, z czasem dystansuje się od tej idei. Natomiast Manfred Brelage podkreśla ścisły związek Hartmannowskiego rozumienia historii filozofii jako historii problemów z koncepcją nauczyciela Hartmanna, Hermanna Cohena i pisze: „Ugruntowanie historii filozofii jako historii problemów zostało przez Hartmanna rozwinięte na wzór H. Cohena ugruntowania nauk ścisłych" ${ }^{2}$. Przykład, jaki podaje Brelage, polega na tym, że dla Cohena metoda transcendentalna wychodząc od faktu przyrodoznawstwa pyta o warunki jego możliwości, a tymczasem Hartmann pyta: ,jak jest możliwa czysta historia problemu?"3. Odpowiedź na tak postawione pytanie jest równocześnie wskazaniem na rozumienie filozofii. Można się tu doszukać związku z tezą Hegla, który w Wykładach z historii filozofii akcentuje ścisły związek filozofii z jej historią i pisze:

Chciałbym tu jeszcze tylko zwrócić uwagę na to, że z tego, co zostało powiedziane, wynika, iż studiowanie historii filozofii jest studiowaniem samej filozofii i inaczej być nie może $e^{4}$.

Po drugie, co zostało już zasygnalizowane, Gadamer jest neokantystą marburskim, doktorem wypromowanym w Marburgu przez Paula Natorpa, współtwórcę szkoły marburskiej. Gadamer należy do ostatnich doktorów marburskich, wspólnie z Hinrichem Knittermeyerem (1891-1958). Knittermeyer doktoryzował się w roku 1918 (3 grudnia), zaś Gadamer - w roku 1922, a więc w wieku 22 lat. Ten ostatni wspomina w Autoprezentacji:

1 W. Windelband, Geschichte der Philosophie, Akademische Verlagsbuchhandlung von J.C.B. Mohr (Paul Siebeck), Freiburg i.B. 1892, s. III-IV.

2 „Die Grundlegung der Philosophiehistorie als Problemgeschichte wird von Hartmann nach dem Vorbild von H. Cohen Grundlegung der exakten Wissenschaften entwickelt". M. Brelage, Studien zur Transzendentalphilosophie, Walter de Gruyter \& Co., Berlin 1965, s. 6.

3 N. Hartmann, Zur Methode der Philosophiegeschichte, in: idem, Kleinere Schriften, Bd. 3: Vom Neukantianismus zur Ontologie, Walter de Gruyter \& Co., Berlin 1958, s. 13.

4 G.W.F. Hegel, Wykłady z historii filozofii, t. 1, przeł. Ś.F. Nowicki, przejrzał A. Węgrzecki, Wydawnictwo Naukowe PWN, Warszawa 1994, s. 60. 
Kiedy napisałem moją dysertację poświęconą Platonowi i doktoryzowałem się w roku 1922, o wiele za młody, pozostawałem w głównej mierze pod wpływem Nicolaia Hartmanna, który pozostawał w opozycji do idealistycznego stylu systematyki Natorpa ${ }^{5}$.

Tym, co łączy Gadamera i Knittermeyera jest fakt, że zostali w Marburgu wypromowani właśnie przez Natorpa, ale neokantowska szkoła marburska już w tym czasie nie istniała. Spotkali się także później, kiedy w roku 1958 Knittermeyer opublikował ostatnie dzieło Natorpa, zatytułowane Philosophische Systematik ${ }^{6}$. Gadamer wprawdzie nie kryje się z tym, że jest marburczykiem, ale wskazuje wyraźnie na swoje związki z Martinem Heideggerem, którego przecież też spotkał w Marburgu. Mowa dla uczczenia pamięci Paula Natorpa, która znajduje się w książce Natorpa opublikowanej przez Knittermeyera ${ }^{7}$, została później włączona do autobiografii Gadamera ${ }^{8}$. Skutek tego, że Gadamer studiuje w Marburgu wtedy, kiedy Cohena nie tyle tam nie ma, ile już nie żyje, jest taki, iż trudno go nazwać neokantystą. Sam pisze o tym w następujący sposób:

Ktoś, kto będąc młodym człowiekiem o zainteresowaniach filozoficznych szedł do Marburga, ten miał na myśli szkołę marburską. Wprawdzie Hermann Cohen opuścił Marburg po przejściu na emeryturę i zmarł w roku 1918, ale uczył tam Paul Natorp i obok niego młodsi, jak Nicolai Hartmann i Heinz Heimsoeth?

Kiedy w Marburgu pojawił się Martin Heidegger, wówczas Gadamer ostatecznie zdystansował się względem neokantyzmu.

Po trzecie, relacja Gadamera do szkoły marburskiej jest bardzo złożona. Wskazuje na to uwagę Eggert Winter, który zauważa: „Nietrudno zauważyć pochodzenie Gadamerowskiej koncepcji «historii oddziaływania», która w procesie rozumienia ujawnia ważność rzeczywistości

5 H.-G. Gadamer, Selbstdarstellung, in: idem, Gesammelte Werke, Bd. 2: Hermeneutik II. Wahrheit und Methode. Ergänzungen. Register, J.C.B. Mohr (Paul Siebeck), Tübingen 1993, s. 482-483.

6 P. Natorp, Philosophische Systematik. Mit der Gedenkrede zum 100. Geburtstag am 24.1.1954 von Hans-Georg Gadamer, Einleitung und textkritische Anmerkungen von H. Knittermeyer, Felix Meiner Verlag, Hamburg 1958.

7 Ibidem, s. XI-XVIII.

8 H.-G. Gadamer, Philosophische Lehrjahre. Eine Rückschau, Vittorio Klostermann, Frankfurt am Main 1977, s. 60-68. Wydanie polskie: Idem, Moja droga do filozofii. Wspomnienia, przeł. J. Wilk, Wydawnictwo Uniwersytetu Wrocławskiego, Wrocław 2000, s. $43-49$.

9 H.-G. Gadamer, Philosophische Lehrjahre..., s. 14. Por. Idem, Moja droga do filozofii..., s. 10 . 
dziejów, od neokantowskiej koncepcji «historii problemów»"10. Tutaj trudność dotyczy terminu „Wirkungsgeschichte”, który w polskim wydaniu Wahrheit und Methode przetłumaczono jako "dzieje efektywne”"11. W zasadzie jest to zgodne z regułami translacji, co uwyraźnia przekład z języka niemieckiego na język angielski. Niemieckie „Wirkungsgeschichte" można oddać jako "history of effects”, "effective history" lub też "reception history" i w zasadzie w pierwszym znaczeniu jest najbliższe idei Gadamera. Stąd „historia oddziaływania”, a nie „dzieje efektywne", co samo w sobie ma sens o tyle, że pierwsze tłumaczenie zdaje się mieć znaczenie neutralne, zaś drugie już nie. Jednakże nie terminologia jest ważna $\mathrm{w}$ zdaniu przytoczonym za Winterem. Kluczowe jest to, że Gadamer realizuje - nawet jeśli bardzo wyraźnie się od neokantyzmu odcina - model, który krytykuje. Dlaczego tak się dzieje?

I.

Gadamer podejmuje kwestię problemu wielokrotnie. W Prawdzie i metodzie odwołuje się do Robina George'a Collingwooda (1889-1943) i sformułowanej przez niego „logiki pytania i odpowiedzi (logic of question and answer)"12. Ujawnia się tu oczywista dwuznaczność na którą wskazuje Gadamer. Pisze tak: „Collingwood argumentuje następująco: dany tekst można rozumieć tylko wtedy, gdy się zrozumiało pytanie, na które jest on odpowiedzią"13 i jako konsekwencję tego faktu dodaje: „[...] wszelkie rozumienie jest zawsze czymś więcej niż samym tylko odtwarzaniem poglądu kogoś innego"14. Gadamer staje się tu rzecznikiem takiego spoj-

10 "Gadamers Konzept «Wirkungsgeschichte», das im Verstehenprozeß die Wirklichkeit der Geschichte in Geltung bringt, ist unschwer seine Abkunft vom neukantianischen Konzept der «Problemgeschichte» anzumerken". E. Winter, Ethik und Rechtswissenschaft. Eine historisch-systematische Untersuchung zur Ethik-Konzeption des Marburger Neukantianismus im Werke Hermann Cohens, Duncker \& Humblot, Berlin 1980, s. 94.

11 Zob. H.-G. Gadamer, Prawda i metoda. Zarys hermeneutyki filozoficznej, przeł. B. Baran, Wydawnictwo Naukowe PWN, Warszawa 2007, s. 412. W odniesieniu do tytułu dzieła Gadamera warto zwrocić uwagę na słowa Paula Ricoeura, który w tym kontekście zauważa: „Już tytuł jego dzieła konfrontuje Heideggerowskie pojęcie prawdy z Diltheyowskim pojęciem metody. Pytanie tylko, do jakiego stopnia dzieło to zasługuje na tytuł Prawda i metoda i czy nie należałoby raczej nazwać je Prawda czy metoda". P. Ricoeur, Zadanie hermeneutyki, w: idem, Jezzyk, tekst, interpretacja. Wybór pism, przeł. P. Graff, K. Rosner, oprac. K. Rosner, Państwowy Instytut Wydawniczy, Warszawa 1989, s. 218-219.

12 Zob. ibidem, s. 503-515.

13 Ibidem, s. 504.

14 Ibidem, s. 510. 
rzenia na dzieje, jakie dotychczas - $\mathrm{w}$ jego przekonaniu - nie miało miejsca i akcentuje konieczność zdystansowania się względem neokantyzmu i stwierdza:

Rozwijana przez Collingwooda logika pytania i odpowiedzi kładzie kres mówieniu o stałym problemie, co leżało u podstaw stosunku «oksfordzkich realistów» do klasyków filozofii, a także rozwiniętemu przez neokantyzm pojęciu dziejów problemu. Dzieje problemu byłyby naprawdę dziejami tylko wtedy, gdyby uznały tożsamość problemu za pusty abstrakt, a siebie za zmienne w trakcie stawiania pytan ${ }^{15}$.

W ostatnim zdaniu gubi się nieco sens poszukiwanego wyjaśnienia, gdyż w oryginale brzmi ono: „Problemgeschichte wäre nur wahrhaft Geschichte, wenn sie die Identität des Problems als eine leere Abstraktion erkennen und sich den Wandel in den Fragestellungen eingestehen würde"16. To zaś oznacza, że Gadamer mówi tu o „historii problemów”.

Gadamer rezygnuje jednak z wyjaśnienia, dlaczego problem nie może być traktowany jako abstrakt. Spoglądając na neokantowskie ujęcie problemu teoriomnogościowo rzec można, że stałość problemu polega na tym, iż jest właśnie zbiorem podpadających pod niego aktualnych ujęć. To jednak nie wystarcza Gadamerowi, który kontynuuje:

Nie istnieje stanowisko poza historia, z którego można by rozważać tożsamość jakiegoś problemu pośród przemian jego historycznych prób rozwiązania. To prawda, że wszelkie rozumienie tekstów filozofii wymaga ponownego rozpoznania tego, co $\mathrm{w}$ nich poznawane. W przeciwnym razie nie rozumielibyśmy nic zgoła. Przez to jednak w żadnym razie nie wykraczamy poza uwarunkowania historyczne, wśród których się znajdujemy i na podstawie których rozumiemy ${ }^{17}$.

Gadamer jest więc przekonany, że konieczność uwzględnienia uwarunkowań historycznych stanowi przeszkodę w ujęciu tego, co ponadhistoryczne. Pozostaje tym samym w jawnej opozycji do Hartmanna, mówiącego o konieczności oddzielenia tego, co historyczne i ponadhistoryczne i na konieczności tego odróżniania budującego swoją krytyczną ontologię. Hartmannowskie podejście do Kanta opiera się na nieodzowności wskazania tego, co u autora Krytyki czystego rozumu uwarunkowane jest idealizmem transcendentalnym, a co nie - wskazanie tego

15 Ibidem, s. 511.

16 H.-G. Gadamer, Wahrheit und Methode, in: idem, Gesammelte Werke, Bd. 1: Hermeneutik I. Wahrheit und Methode. Grundzüge einer philosophischen Hermeneutik, J.C.B. Mohr (Paul Siebeck), 6. Aufl. Tübingen 1990, s. 381.

17 H.-G. Gadamer, Prawda i metoda..., op. cit., s. 511. 
zawarte jest w podtytule artykułu podejmującego tę kwestię ${ }^{18}$. Innymi słowy, Gadamer nie może znaleźć stanowiska, które Hartmannowi znaleźć się udaje. Nie jest prawdą - mógłby ktoś zaoponować, że Hartmann znalazł takie "stanowisko poza historią"19, którego nie udało znaleźć się Gadamerowi, gdyż jego sformułowanie głównych problemów filozofii Kanta również podlega uwarunkowaniom historycznym. To prawda, choć problem jest bardziej złożony. Sam Gadamer odpowiada: „Czystą iluzją jest stanowisko poza wszelkimi stanowiskami, z którego można by rozpatrywać prawdziwą tożsamość tego problemu" ${ }^{20}$. Czy rzeczywiście?

Nieprzypadkowo - o czym będzie jeszcze mowa - Gadamer odwołuje się do neokantyzmu i jego ujęcie historii filozofii czyni przedmiotem ataku.

Neokantowskie dzieje problemów to bękart historyzmu. Przeprowadzona za pomocą logiki pytania i odpowiedzi krytyka pojęcia problemu musi rozwiać złudzenia, że problemy istnieją jak gwiazdy na niebie ${ }^{21}$.

Oczywiście problemem jest historyzm, ale jeszcze większym problemem jest problem nauki, a tego Gadamer zdaje się nie dostrzegać. Autor Prawdy i metody odwołuje się w przypisie do tekstu Hartmanna zatytułowanego Myśl filozoficzna i jej historia i pisze:

Nicolai Hartmann w Der philosophische Gedanke und seine Geschichte, «Abhandlungen der Preußischen Akademie der Wissenschaften» 5 (1936), słusznie podkreśla, że chodzi o ponowne poznanie tego, co poznali wielcy myśliciele. Gdy jednak dla obrony trwałości przed historyzmem odróżnia od zmienności problemów i sytuacji problemowych stałość «właściwej zawartości problemowej», wówczas zapoznaje, że ani «zmiana», ani «stałość», ani też przeciwstawienie «problemu» i «systemu», ani wreszcie kryterium «osiągnięć» nie odpowiadają poznawczemu charakterowi filozofii ${ }^{22}$.

Gadamer, jak wiadomo, jest zwolennikiem historii pojęć: „Ponieważ w filozofii idzie o jedność pojęcia" ${ }^{23}$. Z tej też perspektywy neokantowska wizja historii jako historii problemów ,jest niewystarczająca" ${ }^{24}$.

18 Zob. N. Hartmann, Diesseits von Idealismus und Realismus. Ein Beitrag zur Scheidung des Geschichtlichen und Übergeschichtlichen in der Kantischen Philosophie, in: idem, Kleinere Schriften, Bd. 2: Abhandlungen zur Philosophie-Geschichte, Walter de Gruyter \& Co., Berlin 1957, s. 278-322.

19 H.-G. Gadamer, Prawda i metoda..., op. cit., s. 511.

20 Ibidem.

21 Ibidem, s. 512-513.

22 Ibidem, s. 513.

23 H.-G. Gadamer, Hermeneutik II..., s. 80.

24 Ibidem, s. 81. 
Gadamer odwołuje się do Hartmanna i mówi: „Nicolai Hartmann, któremu tutaj wszyscy wiele zawdzięczamy, sformułował to ostrożnie: właściwy sens historii problemów stanowi wyostrzenie (i stałe udoskonalanie) świadomości problemu. Na tym polega postęp filozofii" ${ }^{25}$. Przykładem problemu jest dla Gadamera problem wolności, a używa go w celu wykazania, że historia filozofii jako historia problemów jest niemożliwa. Nie to jest jednak istotne w tym miejscu. Gadamer bowiem przy okazji wskazuje na niezwykle istotny element teorii problemu i pisze: „Warunek bycia problemem filozoficznym polega bowiem w rzeczywistości na tym, aby być nierozwiązywalnym"26. Oznacza to jeszcze jeden element filozofii neokantowskiej w doktrynie Gadamera. Interesujące natomiast jest to, że pytając o problem wolności Gadamer zadaje intrygujące pytanie, które brzmi: „Czy istnieje problem wolności? Czy rzeczywiście pytanie o wolność jest takie samo po wsze czasy?"27. Co ciekawe, Gadamer mówi o problemie wolności w kontekście jego identyczności w wykładzie wygłoszonym na posiedzeniu „Arbeitsgemeinschaft für Forschung des Landes Nordrhein-Westfalen" w Düsseldorfie w dniu 15 października 1969 roku, a więc rok wcześniej wobec uwag zamieszczonych w drugim tomie Wahrheit und Methode. Gadamer pyta tam:

Czy w pojęciu problemu nie tkwi tajemnicza, niewyjaśniona dogmatyka? Przykład może przybliżyć te wątpliwości: czy jest sens mówić o tożsamości problemu wolności, jak gdyby ten problem był kiedyś dostępny myśleniu inaczej, w ciągle nowych, aktualnych motywacjach, które podejmują możliwość bądź rzeczywistość wolności w ciagle nowym $\mathrm{i}$ innym sensie ${ }^{28}$.

Skoro nie ma jednego problemu wolności, to znaczy, że nie istnieje problem wolności jako taki, a to znaczy, że niemożliwa jest historia problemów. Gadamer jednocześnie zakłada, że historia filozofii rozumiana jako historia problemów to nic innego, jak „radykalizacja historyzmu” polegająca na tym, że „poszukuje się krytycznego przezwyciężenia takiego naiwnego przeglądania się w lustrze (Selbstbespiegelung)"29. Nie jest też jednocześnie tak, że krytyce podlega historia problemu in extenso. Gadamer bowiem uważa, że „uzasadniony motyw «historii problemów», ponowne rozpoznanie własnych pytań w historii, pozostaje w mocy. Rozwiązanie identycznego problemu nie prowadzi do całko-

25 Ibidem.

26 „Die Bedingung, ein philosophisches Problem zu sein, besteht nämlich in Wahrheit darin, unlösbar zu sein". Ibidem.

27 Ibidem, s. 81-82.

28 H.-G. Gadamer, Die Begriffsgeschichte und die Sprache der Philosophie, Springer Fachmedien Wiesbaden GmbH, Wiesbaden 1971, s. 8.

29 Ibidem. 
witej bezpodstawności dowolnych mniemań i teorii, na które rozpada się historia filozofii" ${ }^{\prime 30}$. Dodatkowo powtarza argument, że prawdziwe problemy są nierozwiązalne.

Odpowiedzią Gadamera na neokantowską wizję problemów filozoficznym jest oczywiście hermeneutyka. Jest to tym bardziej konieczne, że Gadamer nie uświadamia sobie pewnych kwestii, kiedy na przykład pisze:

Słabością historii problemu było to, że historię filozofii mogła odczytywać tylko jako potwierdzenie własnego rozumienia problemu, a nie jako krytycznego partnera, który odkrywa nasze własne rozumienia w ich ograniczoności ${ }^{31}$.

Przytoczone zdanie sugeruje, że neokantyści nie posiadaliby świadomości granic poznania, co jest nieco niezrozumiałym zarzutem pod adresem tych, którzy do Kanta nieustannie się odwołują. Ujęcie historii filozofii z perspektywy hermeneutyki Gadamera staje się bardziej zrozumiałe, kiedy uświadomić sobie kwestię roli, jaką odgrywa w jego myśleniu Martin Heidegger. „Kiedy Heidegger rozpoczynał swą drogę myślowa odwrót od historii problemów w pewnym sensie wisiał w powietrzu" ${ }^{32}$. Odwrót od historii problemów, który Gadamer wiąże z Heideggerem, jest symptomatyczny dlatego, że oznacza to, co koniec końców fundamentalne dla Gadamerowskiej krytyki historii problemów: rozumienie filozofii. Inna sprawa, że Gadamer dostrzega pewną jedność swojej wizji historii filozofii z wizją neokantowską kiedy w Dodatku wywołanym dyskusją po swoim wykładzie zauważa:

W dyskusji zwrócono uwagę na bezsprzecznie wielkie osiągnięcia, które szczególnie wykazywała marburska historia problemów. Chodzi o takie nazwiska jak Ernst Cassirer, Richard Hönigswald, Nicolai Hartmann, Heinz Heimsoeth. Można się słusznie zapytać, z czego musi zrezygnować historia pojęć. Albo można zapytać: czy historia pojęć jest więc w ogóle czymś innym? Czy na samym końcu nie jest ona oddogmatyzowaną tzn. historią problemów wyłączoną z systematycznych ram filozofii neokantowskiej, by tak rzec, jej właściwą prawdą? W rzeczywistości jest to zadanie naszego historycznego samozrozumienia, tak rozumieć żyjącego partnera, jak też historycznego partnera od strony ich własnych pytań, a mimo to podejrzewać go przy tym o coś, czego on wcale nie powiedział. Ponieważ idzie o to, aby wspólne rzeczy, o które tu chodzi, uwyraźnić sobie z perspektywy własnego stanowiska. Stanowi to uzasadnioną kon-

30 Ibidem, s. 9.

31 H.-G. Gadamer, Hermeneutik II..., op. cit., s. 113.

32 H.-G. Gadamer, Die Geschichte der Philosophie, in: idem, Gesammlte Werke, Bd. 3: Neuere Philosophie I. Hegel - Husserl - Heidegger, J.C.B. Mohr (Paul Siebeck), Tübingen 1987, s. 298. 
sekwencję hermeneutyki pytania. Byłoby niesprawiedliwe historii problemów odmawiać świadomości tej konsekwencji ${ }^{33}$.

II.

Przywołany przez Gadamera Collingwood w swej książce The idea of history pisze:

Historyk filozofii, czytający Platona usiłuje zrozumieć co Platon myślał, kiedy posługiwał się pewnymi słowami. Może on to zrobić tylko przez wywołanie $\mathrm{w}$ sobie tych samych myśli. i to jest właśnie to o co nam chodzi, gdy mówimy o «zrozumieniu» wyrazów ${ }^{34}$.

Jest to teza, z którą w żadnym razie nie zgodzi się Nicolai Hartmann. W tekście opublikowanym po raz pierwszy w roku 1936 zauważa:

To, co uważa się za prawdziwą historię filozofii zależy od tego, co właściwie uważa się za filozofię. Twierdzę poważnie: klasycy historii filozofii w XIX wieku - podobnie, jak czynili to już starożytni doksografowie - na ogół za istotę filozofii uważali doktryny i konstrukcje systemowe. Stąd ich wrażliwość na bogactwo myśli, głębie, oryginalność, zwartość (Geschlossenheit) obrazów świata, historyczną skuteczność; a ponadto na wędrówkę wątków myślowych i zmiany ich kształtu. Stąd też drażliwy niedostatek sensu wobec historycznego rozwoju problemów, wobec tego, co w pracy życiowej wielkich myślicieli i całych wieków stanowi postępujące wnikanie, zrozumienie i osiągnięcie. Podnosi się więc wobec tego postulat badania historii, które ma do czynienia z filozoficznymi rozumieniami i osiągnięciami. W odniesieniu do niego sprawą najważniejszą i ostateczną nie jest to, aby «zrozumieć», co myśliciele myśleli, mniemali, czego uczyli, lecz «ponowne rozpoznanie» tego, co oni poznali ${ }^{35}$.

Nieco inaczej, ale w analogicznym znaczeniu zauważa Hartmann na początku rozprawy poświęconej Kantowi: „Nie chcę tu przemawiać

33 H.-G. Gadamer, Die Begriffsgeschichte und die Sprache der Philosophie..., s. 20.

34 R.G. Collingwood, O pojęciu historii, przeł. T. Terlecki, w: Wspótcześni historycy brytyjscy. Wybór z pism, Wstęp G.P. Gooch, opracowanie J.Z. Kędzierski, Polskie Towarzystwo Historyczne na Obczyźnie, Londyn 1963, s. 136.

35 N. Hartmann, Der philosophische Gedanke und seine Geschichte, in: idem, Kleinere Schriften, Bd. 2: Abhandlungen zur Philosophie-Geschichte, Współcześni historycy brytyjscy. Wybór z pism Berlin 1957, s. 11. Tłumaczenie polskie: Idem, Myśl filozoficzna i jej historia, przeł. J. Garewicz, w: N. Hartmann, Myśl filozoficzna i jej historia. Systematyczna autoprezentacja, Wydawnictwo Comer, Torun 1994, s. 23 (dalej cytowane odpowiednio jako PhG oraz MF). Przekład Jana Garewicza nieco modyfikuję. 
o Kancie jako historyk, lecz jako systematyk, nie chcę interpretować, co Kant myślał, lecz uwypuklić to, w czym wyprzedził nas i nasze czasy"36.

W świetle powyższego problem przedstawia się następująco: albo historia filozofii ma być zajęciem opisowo-rekonstruującym, albo też rozumiejącym. W naturalny sposób nasuwa się tu analogia do dziejów neokantyzmu, a mianowicie odróżnienia tzw. filologii Kantowskiej od właściwego neokantyzmu. W pierwszej fazie próbowano dociec, co mówiąc kolokwialnie - Kant miał na myśli, natomiast druga rozpoczęła się od słynnego hasła Windelbanda: „zrozumieć Kanta oznacza wykroczyć poza niego" ${ }^{\prime 37}$. W pierwszym wypadku usiłuje się znaleźć jakiegoś mitycznego „rzeczywistego" Kanta, w drugim - sens badań sprowadza się do tego, by zrozumieć, na czym polega jego filozofia i jak wpisuje się w rozumienie problemu. Przy okazji zresztą pojawia się bardzo wyraźnie problem „neofilozofii” w ogóle, gdyż wywodzący się z badeńskiej szkoły neokantyzmu, wrocławianin Richard Kroner (1884-1974), uważany za jednego z głównych reprezentantów neoheglizmu, we Wprowadzeniu do swej słynnej książki zanotował:

Jeśli kiedyś Windelband powiedział: «zrozumieć Kanta oznacza wykroczyć poza niego», to można także powiedzieć, zrozumieć Hegla oznacza uświadomić sobie, że absolutnie poza niego nie można już więcej wyjść. Kiedy chciałoby się podać takie "po-Heglu», to należałoby ustanowić nowy początek ${ }^{38}$.

To nie tylko kwestia słów. Idzie raczej o to, że w ramach neoheglizmu zupełnie inaczej będzie się rozumieć filozofię i historię filozofii niż na gruncie neokantyzmu.

Hartmann w artykule z roku 1936 zwraca uwagę na kilka kwestii. Filozofia $\mathrm{w}$ jego przekonaniu niespecjalnie zajmuje się swoimi dziejami (choć powinna), ale w konsekwencji, jak stwierdza, „[...] musi potem wygrzebywać to, co we wglądach (Einsichten) leży pogrzebane pod gruzami «systemów»"39. Na tym polega, zdaniem Hartmanna, sens badań historycznofilozoficznych, co pozostaje w sprzeczności z tezą Hegla, który w Przedmowie do Zasad filozofii prawa napisał:

Co się tyczy jednostki, to każda jest niewątpliwie dzieckiem swej epoki: podobnie ma się rzecz z filozofią: jest ona swoja własna epoka ujęta w myślach. Tak więc głupotą byłoby przypuszczać, że jakakolwiek filozofia wykra-

36 N. Hartmann, Diesseits von Idealismus und Realismus..., op. cit., s. 278.

37 W. Windelband, Präludien. Aufsätze und Reden zur Einführung in die Philosophie, Bd. 1. 4. Aufl. Verlag von J.C.B. Mohr (Paul Siebeck), Tübingen 1911, s. IV.

38 R. Kroner, Von Kant bis Hegel, Bd.1: Von der Vernunftkritik zur Naturphilosophie, Verlag von J.C.B. Mohr (Paul Siebeck), Tübingen 1921, s. 6.

$39 \mathrm{PhG}, 12(\mathrm{MF}, 24)$. 
cza poza swój współczesny świat, jak że jednostka może przeskoczyć przez swoją epokę $e^{40}$.

Hartmann zarazem potwierdza i kwestionuje tezę Hegla pisząc: „W rzeczy samej każdy myśliciel tkwi oglądzie swej epoki” ${ }^{41}$. Dla niego oznacza to jednocześnie, że dany myśliciel jest mocno zakorzeniony również w przesądach i systemach danej epoki. Dlatego też nieco dalej Hartmann dodaje: „Ale niewątpliwie istnieją wglądy właśnie tych związanych z daną epoką myślicieli, które wychodzą poza te ograniczenia. $\mathrm{W}$ tego typu wglądach tkwi historyczny postęp poznania filozoficznego" $^{\prime \prime 2}$.

Pojęcie postępu jest tym, które jest kluczowe dla neokantystów marburskich, Hartmann odnosi ponadto do historii filozofii. Postęp polega tu na tym, że mamy do czynienia z nową, nieznaną dotychczas perspektywą która ujawnia się z czasem. Występują tu dwa istotne elementy. Pierwszy stanowi to, co w duchu Hartmanna można nazwać „prawem odkrywcy", a co sprowadza się do następującej tezy:

To, co «wiedzą» wielcy myśliciele i podejmują w swej «teorii» (Lehre), rzadko jest identyczne z tym, co oni «widzą» bądź «odkrywają». Nieliczni odkrywcy wiedzą dobrze, co właściwie odkryli; prawie wszyscy podzielają los Kolumba. wiedzą to dopiero epigoni ${ }^{43}$.

Drugi element związany jest $\mathrm{z}$ funkcjonowaniem $\mathrm{w}$ świecie przesądów, które zaciemniają widzenie problemu, a które Gadamer próbuje rozwiązać odwołując się do Heideggerowskiego pojęcia „kręgu hermeneutycznego" i pisze:

Wszelkie rozumienie tego, co znaczące zakłada, że wnosimy związek takich przesądów. Heidegger określił ten stan rzeczy jako krąg hermeneutyczny: rozumiemy tylko to, co już wiemy, możemy wychwycić uchem to, w co się wsłuchaliśmy. Porównanie tego na miarę poznania przyrody wydaje się niemożliwe. $\mathrm{W}$ rzeczywistości tylko dzięki temu możliwe jest rozumienie historyczne. Nie idzie o to, by uniknąć takiego kręgu, lecz o to by właściwie w niego wejśćc ${ }^{44}$.

40 G.W.F. Hegel, Zasady filozofii prawa, przeł. A. Landman, Wydanictwo Naukowe PWN, Warszawa 1969, s. 19.

41 PhG, 12. W tłumaczeniu Jana Garewicza: „Z pewnościa, każdy myśliciel tkwi w poglądach własnych czasów". MF, 25. Problem polega na tym, że Hartmann, zapewne nieprzypadkowo, używa tu rzeczownika "Anschauungen”, co oczywiście znaczy również "pogląd”, ale w pierwszym znaczeniu "ogląd”, „oglądanie”.

$42 \mathrm{PhG}, 13$ (MF, 25).

$43 \mathrm{PhG}, 6(\mathrm{MF}, 61)$.

44 H.-G. Gadamer, Hermeneutik II..., op. cit., s. 34. Por. Idem, Prawda i metoda..., op. cit., s. $376 \mathrm{nn}$. 
Hartmann wskazuje na istniejące tu trudności i podkreśla, że czym innym jest znaleźć problem, a czym innym krytycznie go wyjaśnić ${ }^{4}$. Takie krytyczne wyjaśnienie nie zawsze się udaje, a przykłady podane przez Hartmanna są następujące:

Klasycznym tego przykładem jest Eduard von Hartmann w swej Geschichte der Metaphysik, podobnie Natorp w swym wykładzie Kartezjusza, Platona, Kanta i innych; pierwszy przeszukuje całą historię pod kątem «nieświadomego», drugi - ze wszystkich dawnych myślicieli czyni niedoskonałych neokantystów ${ }^{46}$.

III.

Klucz do zrozumienia niemożliwości uzgodnienia stanowiska Gadamera z doktryną neokantystów zdaje się leżeć bardzo blisko, a jest nim rozumienie filozofii. Zasadnicza różnica polega na tym, że dla Hartmanna - bądź co bądź wywodzącego się ze szkoły marburskiej filozofia jest nauka, a zatem również historia filozofii musi pod ten warunek podpadać. Tymczasem dla Gadamera - wywodzącego się z innej szkoły marburskiej - filozofia nauką nie jest. Zwraca na to uwagę Manfred Brelage, kiedy pisze: „Idea «historii problemów» jest zdeterminowana myślą o autonomii filozofii, nie tylko w stosunku do niefilozoficznego życia duchowego w pozostałych obszarach kultury, lecz także w stosunku do psychiczno-osobowego życia filozofa" ${ }^{47}$. Kwestia autonomii filozofii i jej naukowego charakteru jest kluczowa dla neokantystów marburskich, ale Gadamer - postępując tropem Heideggera - wyraźnie się od niej dystansuje. Czyni to już w roku 1924, podejmując - w księdze jubileuszowej dedykowanej Paulowi Natorpowi - problem systemu. „To, że historia filozofii nie jest po prostu historią nauki, jak na przykład historia matematyki, lecz sama jest filozofia, miano na względzie od zawsze i utwierdzono działalnością naukową" ${ }^{48}$. Tymczasem Hartmann twierdzi wręcz coś odwrotnego i pisze:

Jeśli więc filozofia jest czymś więcej niż tylko samą opinią na temat wszystkiego, co możliwe, jeśli jest ona nauka, to jej właściwa historia musi istnieć w ciągu wglądów, a nie w ciągu mniemań i systemów. Ściśle

45 Zob. PhG, 16 (MF, 64).

46 PhG, 16 (MF, 64).

47 M. Brelage, Studien zur Transzendentalphilosophie..., op. cit., s. 4.

48 H.-G. Gadamer, Zur Systemidee in der Philosophie, in: Festschrift für Paul Natorp zum siebzigsten Geburtstage von Schüllern und Freunden gewidmet, Walter de Gruyter \& Co., Berlin-Leipzig 1924, s. 56. 
biorąc, te ostatnie - o ile nie kryją się za nimi ukryte wglądy - są bowiem tym, co niefilozoficzne w filozofii ${ }^{49}$.

Niemożliwość historii filozofii jako historii problemów filozoficznych wynika u Gadamera z niemożliwości rozumienia filozofii jako nauki. Zauważa to Brelage charakteryzując tendencję epoki:

Wkraczamy w całkowicie nową atmosferę, kiedy przechodzimy od tej koncepcji historii filozofii jako »historii problemów « do filozoficznych teorii dotyczących dziejowości (Geschichtlichkeit) filozofii i struktury historii filozofii, które w Niemczech doszły do głosu po pierwszej wojnie światowej ${ }^{50}$.

Jest to zatem tendencja wspólna dla całej epoki postneokantowskiej, tendencja charakterystyczna przede wszystkim dla takich myślicieli, jak Karl Jaspers i Martin Heidegger, choć oczywiście nie tylko do nich się ograniczająca. Brelage podaje całą listę nazwisk takich, jak Fritz Kaufmann, Ludwig Landgrebe, Michael Landmann i zauważa: „Rozpoczynamy z nowym pojęciem filozofii, które zostało wykoncypowane w przeciwieństwie do idei filozofii jako nauki ścisłej" ${ }^{51}$. Epoka, którą można określić mianem postneokantyzmu, charakteryzuje się tym, że teoriopoznawcze zorientowanie neokantyzmu zastępuje orientacją ontologiczną. Jeszcze inaczej rzecz wygląda u Jaspersa, myśliciela zafascynowanego egzystencją. Z tego też powodu Brelage odwołuje się właśnie do Jaspersa, a ściślej do Posłowia do trzeciego wydania jego książki Philosophie. Jaspers zauważa tam:

Niezmiennie aktualne było dla mnie oburzenie wobec filozofii, która wystąpiła jako nauka i podejmowała się udowodnienia powszechnej ważności. Przyniosło mi to świadomość ryzyka - niebezpieczeństwa dla rzetelności - tego, co wprawdzie jest zrozumiałe tylko dzięki myśleniu, ale nigdy nie jest możliwe do udowodnienia jako nauka ${ }^{52}$.

Nie trzeba dodawać, że również Heidegger podejmuje problem w analogiczny sposób, a Gadamer idzie jego śladem. Heidegger zadaje wprost pytanie: czy filozofia jest nauką? - i odpowiada, że oczywiście

\section{PhG, 17 (MF, 28).}

50 M. Brelage, Studien zur Transzendentalphilosophie..., op. cit., s. 14.

51 Ibidem..., op. cit., s. 16.

52 K. Jaspers, Nachwort (1955) zu meiner "Philosophie" (1931), in: idem, Philosophie, Bd. 1: Philosophische Weltorientierung, 3. Aufl., Verlag von Julius Springer, Berlin-Göttingen-Heidelberg 1956, s. XVIII. 
nie jest ${ }^{53}$. W ten sposób egzystencjalna wykładnia prawdy zastępuje jej rozumienie $\mathrm{w}$ duchu naukowości.

Problem rozumienia filozofii jest jednak bardziej złożony, ponieważ staje się wewnętrznym problemem szkoły marburskiej i zalążkiem różnic ujawniających się między ujęciem Hermanna Cohena a Paula Natorpa. Interesujące jest to, że w roku 1905 Natorp pisze: „Zgodnie ze swym historycznym pojęciem filozofia jest nauką podstawowa, tzn. tą nauka, która powinna zabezpieczyć jedność ludzkich poznań za pomocą wykazania wspólnego ostatecznego fundamentu, na którym wszystkie one polegają" ${ }^{\prime 54}$. A nieco dalej dodaje w duchu szkoły marburskiej: „Pierwsza, podstawową dyscypliną filozoficzną jest nauka o podstawowych prawach nie tylko formalnych, lecz materialnych bądź przedmiotowych prawdach poznania: lo g i k a bądźk ry ty k a po z n a n i a"55. W roku 1911, a następnie w 1918 po raz drugi, wydaje książkę Philosophie. Ihr Problem und ihre Probleme, w której mówi o „[...] bardzo ścisłej jedności filozofii i nauki, jedności dzięki wzajemnej relacji, która nie znosi różnorodności, lecz która właśnie jest jej założeniem" ${ }^{\prime 56}$. Jeszcze dalej idzie Natorp w swej Autoprezentacji, kiedy o filozofii mówi jako o „nauce radykalnej (Radikalwissenschaft)" ${ }^{27}$. Tymczasem w wydanej pośmiertnie przez Knittermeyera książce czytamy: „Filozofia jest więc namysłem, a mianowicie namysłem nad życiem samym, nad niczym innym, niż ono samo, życie"58. W świetle przytoczonego na koniec zdania okazać się może, że Gadamer wcale nie jest tak daleki od nauki swego mistrza, jak się to wydaje przy powierzchownym spojrzeniu.

Gadamer podnosi jeszcze inne zarzuty względem historii problemów i pisze:

Co gwarantuje, że raz widocznie dokonane stany rzeczowe i wynikające stąd wyjaśnienie postawienia problemu zostaje rzeczywiście zachowane po wsze czasy? Czyż historia nie uczy, że wglądy w niegdyś dla nieporównanej jasności podniesionego stanu rzeczy są całkowicie zamknięte w innych czasach $?^{59}$

53 Zob. M. Heidegger, Gesamtausgabe, Bd. 27: Einleitung in die Philosophie, hrsg. von O. Saame, I. Saame-Speidel, Vittorio Klostermann, Frankfurt am Main 1996, s. 13-18 (§ 5: Ist Philosophie eine Wissenschaft?).

54 P. Natorp, Philosophische Propedeutik (Allgemeine Einleitung in die Philosophie und Anfangsgründe der Logik, Ethik und Psychologie) in Leitsätzen zu akademischen Vorlesungen, 2. Aufl., N.G. Elwert'sche Verlagsbuchhandlung, Marburg 1905, s. 3.

55 Ibidem, s. 10.

56 P. Natorp, Philosophie. Ihr Problem und ihre Probleme. Einführung in den kritischen Idealismus, 2. Aufl., Vandenhoeck \& Ruprecht, Göttingen 1918, s. 3.

57 P. Natorp, Selbstdarstellung, in: Philosophie der Gegenwart in Selbstdarstellungen, hrsg. von R. Schmidt, Bd. 1, 2. Aufl., Verlag von Felix Meiner, Leipzig 1923, s. 165.

58 P. Natorp, Philosophische Systematik..., s. 3.

59 H.-G. Gadamer, Zur Systemidee in der Philosophie..., op. cit., s. 60. 
Tym samym ujawniając, że - sam będąc platonikiem - ma problemy z rozumieniem platonizmu. Identyfikacja problemu sprawia Gadamerowi kłopoty, których mógłby uniknąć idąc tropem Platona Warto wskazać fragment tekstu Bogdana Dembińskiego:

Już $\mathrm{w}$ trakcie analiz prowadzonych przez Platona w Parmenidesie, jak również $\mathrm{w}$ dialogach wcześniejszych, okazało się, że zauważalna jest zasadnicza różnica $\mathrm{w}$ statusie ontycznym idei i zjawiska. Wynika to zresztą z samego założenia koncepcji uczestnictwa, która domaga się $\mathrm{z}$ istoty swojej przyjęcia różnicy między tym, co uczestniczy, a tym, w czym uczestniczy to, co uczestniczy ${ }^{60}$.

Co więcej, Gadamer nie chce, zdaje się, dostrzec tego, że w gruncie rzeczy problem identyfikacji nie istnieje także wówczas, kiedy uświadomić sobie problem oraz jego rozumienie, aktualne ujęcie, a więc różnicę pomiędzy ordo essendi a ordo cognoscendi - porządkiem bytowania a porządkiem poznawania. Fakt, że nie można problemu identyfikować jako tożsamego z ujętym wcześniej, nie jest równoznaczny z tym, że mamy do czynienia z egzemplifikacjami (historycznymi - jeśli o to idzie Gadamerowi) tego samego problemu.

Interesujące jest to, że młody Gadamer dostrzega zasadność neokantowskiego projektu historii filozofii jako historii problemów, choć ma kilka uwag i w roku 1924 pisze:

Biorąc pod uwagę to jednoznaczne kontrświadectwo historii nie może być w ogóle mowy o wieczności problemów, jeśli są przez to pomyślane problemy, tak jak zostały one sformułowane w historii filozofii. Raczej istnieje tu obiektywizacja pojęcia problemu: to, co jest sformułowane w historycznych problemach, jest identyczne co do swej przedmiotowej zawartości: wszystkie sformułowania historii są próbami uchwycenia tego, co identyczne: mogą tego nie utrafić, $\mathrm{w}$ różnym stopniu mogą to właściwie oceniać - w każdym razie jednak są one odniesione do identycznego stanu problemu, który jest ściśle powiązany ze strukturą samej rzeczy. Jeśli więc własna teraźniejszość pracuje $\mathrm{w}$ tych zawsze identycznych stanach problemu i ich ujęciu, jest ona całkowicie uprawomocniona, kiedy rozbija granice metafizycznej skłonności, w jakiej filozofowie przeszłości widzieli problemy, i jeśli kieruje swoją uwagę na pozytywne badanie problemów w nich samych, tak jak posuwając się naprzód wnika we własne badania. Nie ulega jednak wątpliwości, że nie w każdym czasie stany problemu są $\mathrm{w}$ równym stopniu widoczne, ale ich zasadnicza widzialność wystarczy do tego, aby umożliwić pozytywną ocenę historii ${ }^{61}$.

60 B. Dembiński, Teoria idei. Ewolucja myśli Platońskiej, Wydawnictwo Uniwersytetu Śląskiego, Katowice 1997, s. 108.

61 H.-G. Gadamer, Zur Systemidee in der Philosophie..., op. cit., s. 60-61. 
Natomiast w innym miejscu Gadamer podkreśla:

Rozpoznawany przez nas problem, jeśli ma być rozumiany w procesie rzetelnego zapytywania, nie jest po prostu ten sam. Tylko z racji własnej historycznej krótkowzroczności możemy uważać go za ten sam ${ }^{62}$.

Kłopot zdaje się polegać na tym, że - pomijając odniesienie do Platona - "ten sam" nie jest tożsame z "taki sam”. Gadamer jednak nie chce tego dostrzec.

IV.

Gadamer w swej krytyce historii problemów odwołuje się do historyzmu i jego braków ${ }^{63}$, spośród których najważniejszym jest niezrozumienie własnej dziejowości. „Myślenie rzeczywiście historyczne - stwierdza Gadamer na kartach Prawdy i metody - musi uwzględniać także własną dziejowość" ${ }^{\prime \prime}$. W innym miejscu Gadamer natomiast pisze:

Znamienne, że w XIX wieku, wraz z upadkiem tradycji bezpośredniego stawiania pytań filozoficznych i nadejściem historyzmu, pojęcie problemu zyskuje powszechne uznanie - znak tego, że przestał istnieć bezpośredni stosunek do pytań filozofii. Zamęt w świadomości filozoficznej $\mathrm{w}$ obliczu historyzmu cechuje to, że uciekała ona $\mathrm{w}$ abstrakcje pojęcia problemu, nie widząc żadnego problemu w tym, jak właściwie problemy «istnieją» ${ }^{65}$.

Tym, co uderza, jest sformułowany przez Gadamera pod adresem neokantyzmu - nie wprost odnosi się to do stanowiska Hermanna Cohena - zarzut historyzmu. Z pewnością neokantyzm, jak każda jednostronnie zorientowana filozofia, może się stać i często jest łatwym celem dla krytyków. Rzecz jednak w tym, że nie można zarzucić neokantystom historyzmu. Oczywiste jest to, że historyzm natomiast nie uwzględnia dziejowości, zaś ukazanie tej słabości historyzmu stało się - zdaniem Gadamera - zasługą Wilhelma Diltheya. Dodatkowo okazuje się, że Dilthey próbuje ugruntować nauki humanistyczne i historyczne w opozycji do stanowiska teoriopoznawczego szkoły marburskiej, a pojęciem

62 H.-G. Gadamer, Prawda i metoda..., op. cit., s. 511.

63 Zob. S. Rohm, Objektiver Geist und Ontologie der Sprache. Nicolai Hartmann und Hans-Georg Gadamer, LIT Verlag, Berlin 2008, s. 137-145.

64 H.-G. Gadamer, Prawda i metoda..., op. cit., s. 411.

65 Ibidem, s. 512. 
nadrzędnym staje się dla niego pojęcie „,̇̇ycia”"66. Wychodząc z tego założenia, Dilthey nie uznaje za naukę filozofii historii ani też socjologii ${ }^{67}$.

Eggert Winter zauważa, że już Hermann Cohen dokonał pierwszej krytyki hermeneutyki ze strony, wówczas jeszcze nie istniejącej, szkoły marburskiej, gdyż odniósł się do niej już w roku 1871 w zakończeniu artykułu poświęconego dyskusji, jaką między sobą toczyli Kuno Fischer i Adolf Trendelenburg68. Cohen zauważa tam:

Zarazem jednak owe narzędzia tego, co przyszłe są probierzem tego, co przeszłe. Historyczne połączenie z tym, co dawne można sporządzić tylko w tym, a historyczna znajomość tego, co dawne otwiera się tylko na to, co także w tym, co dawne było nowe. Ponadto łączymy się wewnętrznie z tym, co nowe: musimy brać udział w tym, co nowe jako adwokaci prawdy brać udział, jeśli ma się nam powieść rzeczywista historia ${ }^{69}$.

Winter twierdzi, że właśnie w tym zdaniu - „[...] historyczna znajomość tego, co dawne otwiera się tylko na to, co także w tym, co dawne było nowe” - zawiera się według Cohena "hermeneutyczna aporia fundamentalna (die hermeneutische Grundaporie)"70. Wynika ona $\mathrm{z}$ innego stosunku do dziejów filozofii niż ten, jaki reprezentowali romantycy.

Jego rozważania polegają zatem na tym, że historyk filozofii nie ma dostępu do dzieła filozoficznego, zgodnie z wyobrażeniem romantyków, dzięki niezapośredniczonemu odczuwaniu sytuacji autora, lecz znajduje go dzięki refleksyjnemu ponownemu rozwojowi aktualnej sytuacji problemowej w materiale historycznym. Według tego modelu możliwość uchwycenia myśli historycznej polega na wspólnocie (Gemeinsamkeit), która historyka filozofii łączy z tradycją problemów ${ }^{71}$.

66 Zob. S. Rohm, Objektiver Geist und Ontologie der Sprache..., op. cit., s. 142.

67 Zob. W. Dilthey, Einleitung in die Geisteswissenschaften. Versuch einer Grundlegung für das Studium der Gesellschaft und der Geschichte, Bd. 1, Verlag von B.G. Teubner, Leipzig 1883, s. 108-116.

${ }_{68}$ Zob. na ten temat A.J. Noras, Debata Trendelenburg - Fischer. Problem obiektywności Kantowskich form zmysłowości, „Przegląd Filozoficzny - Nowa Seria” 2013, R. 22, nr 1, s. 267-297; por. Idem, Historia neokantyzmu, Wydanictwo Uniwersytetu Śląskiego, Katowice 2012, s. 124-153.

69 H. Cohen, Zur Controverse zwischen Trendelenburg und Kuno Fischer, "Zeitschrift für Völkerpsychologie und Sprachwissenschaft: Hrsg. von M. Lazarus, H. Steinthal. Berlin 1871, Bd. 7, s. 296.

70 E. Winter, Ethik und Rechtswissenschaft..., op. cit, s. 96.

71 Ibidem, s. 96-97. 
V.

Kwestia rozumienia historii filozofii jako historii problemów filozoficznych, która jest charakterystyczna dla neokantyzmu, okazuje się dla Gadamera niemożliwa do utrzymania. Sytuacja jest jednak tak skomplikowana, że trudno o jednoznaczną ocenę jego stanowiska, gdyż sam neokantyzm stwarza wiele trudności. Ponieważ jednak w zakończeniu rozważań należy się pokusić o pewną ocenę, warto wskazać na kilka kwestii.

1. Autor Prawdy i metody kwestionuje neokantyzm, a w konsekwencji odrzuca rozumienie filozofii jako nauki. Kwestia nie jest jednoznaczna nawet w odniesieniu do samej szkoły marburskiej, gdyż od roku 1912, tj. od przejścia na emeryturę Cohena i opuszczenia Marburga, zaczynają się ujawniać różnice między nim a Natorpem. Jest to istotne, ponieważ kiedy Gadamer tam przybywa, nie jest to już Marburg Cohena i Natorpa, lecz Marburg Natorpa, Hartmanna i Heimsoetha, a w pewnym sensie również Heideggera.

2. Gadamer idzie tropem swoich duchowych mistrzów, spośród których bardzo często wymienia i wskazuje na Heideggera, nie przywiązując dużej wagi do Jaspersa. Problem polega na tym, że jednak raczej ten drugi zdaje się tu odgrywać bardzo istotną rolę. Przede wszystkim wtedy, kiedy akcentuje niemożliwość postępu w filozofii. W Philosophie Jaspers zauważa: „Tam, gdzie wiedza zwraca się do tego, co ponadczasowo słuszne, znajdujemy się $\mathrm{w}$ procesie postępu, ciągle posiadamy więcej niż nasi poprzednicy, stoimy na ich barkach"72, by w Einführung in die Philosophie stwierdzić: „Myślenie filozoficzne nie ma także charakteru postępującego procesu, jak nauki"73. Przeciwstawienie jest proste: postęp możliwy jest w nauce, a skoro filozofia nie jest nauka, to nie ma możliwości postępu. $W$ ten sposób rozważania postneokantystów współgrają z osiągnięciami hermeneutyki - Heidegger jest zresztą jednym i drugim.

3. Gadamer odwołuje się do "historii oddziaływania” (Wirkungsgeschichte), jako jedynego pryncypium, co wzmaga trudności interpretacyjne w odniesieniu do dziejów. Mając to na względzie zauważa: „Raczej rozumienie jest zawsze procesem stapiania się takich rzekomo dla siebie istniejących horyzontów" ${ }^{\prime \prime 74}$. Z tej perspektywy niemożliwa jest filozofia

72 K. Jaspers, Philosophie, Bd. 1..., op. cit., s. 281.

73 „Das philosophische Denken hat auch nicht, wie die Wissenschaften, den Charakter eines Fortschrittsprozesses". K. Jaspers, Einführung in die Philosophie. Zwölf Radiovorträge, 28. Aufl., Piper Verlag, München-Zürich 1989, s. 9. Por. Idem, Wprowadzenie do filozofii. Dwanaście odczytów radiowych, przeł. A. Wołkowicz, Siedmioróg, Wrocław 1995, s. 5.

74 H.-G. Gadamer, Prawda i metoda..., op. cit., s. 420. 
refleksji, co zgodnie podkreślają myśliciele tacy jak Jaspers, Heidegger i oczywiście Gadamer.

\section{Streszczenie}

\section{Problem historii filozofii. Część druga}

\section{Słowa kluczowe}

historia filozofii; historia pojęć; historia problemów; Hans-Georg Gadamer; Nicolai Hartmann

Relacja między filozofią a jej historią stanowi istotny element refleksji filozoficznej w neokantyzmie szkoły badeńskiej i szkoły marburskiej. Związany z duchem szkoły, choć do niej nienależący Hans-Georg Gadamer podejmuje - w imię historii pojęć - dyskusję z rozumieniem historii filozofii jako historii problemów filozoficznych. Analizy prowadzą do wniosku, że kluczem do zrozumienia odmienności między stanowiskiem neokantystów (zwłaszcza Hartmanna) a stanowiskiem Gadamera jest rozumienie filozofii. neokantyści pojmują filozofię jako naukę, zaś Gadamer idzie tropem Heideggera negującego naukowy charakter filozofii.

\section{Summary}

\section{The problem of the history of philosophy. Part two}

\section{Keywords}

history of philosophy; history of concepts; history of problems; Hans-Georg Gadamer; Nicolai Hartmann

Relation between philosophy and its history is an important element of philosophical reflection in both Baden and Marburg school of neo-Kantianism. Associated with the spirit of the school although not a member of it Hans-Georg Gadamer starts, in the name of history of concepts, a discussion with understanding of philosophy as a history of philosophical problems. Analysis leads to a conclusion that the key to understanding the difference between the position of Neo-Kantians (especially Hartmann) and the position of Gadamer is the under- 
standing of philosophy. Neo-Kantians considers philosophy as a science while Gadamer follows Heidegger who negates a scientifical character of philosophy.

\section{Bibliografia:}

Brelage M., Studien zur Transzendentalphilosophie, Walter de Gruyter \& Co., Berlin 1965.

Cohen H., Zur Controverse zwischen Trendelenburg und Kuno Fischer, "Zeitschrift für Völkerpsychologie und Sprachwissenschaft", hrsg. von M. Lazarus, H. Steinthal. Berlin 1871, Bd. 7.

Collingwood R.G., O pojęciu historii, przeł. T. Terlecki, w: Współcześni historycy brytyjscy. Wybór z pism, Wstęp G.P. Gooch, opracowanie J.Z. Kędzierski, Polskie Towarzystwo Historyczne na Obczyźnie, Londyn 1963.

Dembiński B., Teoria idei. Ewolucja myśli Platońskiej, Wydawnictwo Uniwersytetu Śląskiego, Katowice 1997.

Dilthey W., Einleitung in die Geisteswissenschaften. Versuch einer Grundlegung für das Studium der Gesellschaft und der Geschichte, Bd. 1, Verlag von B.G. Teubner, Leipzig 1883.

Gadamer H.-G., Die Begriffsgeschichte und die Sprache der Philosophie, Springer Fachmedien Wiesbaden GmbH, Wiesbaden 1971.

Gadamer H.-G., Die Geschichte der Philosophie, in: Idem, Gesammlte Werke, Bd. 3: Neuere Philosophie I. Hegel - Husserl - Heidegger, J.C.B. Mohr (Paul Siebeck), Tübingen 1987.

Gadamer H.-G., Moja droga do filozofii. Wspomnienia, przeł. J. Wilk, Wydawnictwo Uniwersytetu Wrocławskiego, Wrocław 2000.

Gadamer H.-G., Philosophische Lehrjahre. Eine Rückschau, Vittorio Klostermann, Frankfurt am Main 1977.

Gadamer H.-G., Prawda i metoda. Zarys hermeneutyki filozoficznej, przeł. B. Baran, Wydawnictwo Naukowe PWN, Warszawa 2007.

Gadamer H.-G., Selbstdarstellung, in: idem, Gesammelte Werke, Bd. 2: Hermeneutik II. Wahrheit und Methode. Ergänzungen. Register, J.C.B. Mohr (Paul Siebeck), Tübingen 1993.

Gadamer H.-G., Wahrheit und Methode, in: idem, Gesammelte Werke, Bd. 1: Hermeneutik I. Wahrheit und Methode. Grundzüge einer philosophischen Hermeneutik, 6. Aufl., J.C.B. Mohr (Paul Siebeck), Tübingen 1990.

Gadamer H.-G., Zur Systemidee in der Philosophie, in: Festschrift für Paul Natorp zum siebzigsten Geburtstage von Schüllern und Freunden gewidmet, Walter de Gruyter \& Co., Berlin-Leipzig 1924, s. 55-75.

Hartmann N., Der philosophische Gedanke und seine Geschichte, in: idem, Kleinere Schriften, Bd. 2: Abhandlungen zur Philosophie-Geschichte, Walter de Gruyter \& Co., Berlin 1957, s. 1-48.

Hartmann N., Diesseits von Idealismus und Realismus. Ein Beitrag zur Scheidung des Geschichtlichen und Übergeschichtlichen in der Kantischen Philosophie, in: idem, Kleinere Schriften, Bd. 2: Abhandlungen zur Philosophie-Geschichte, Walter de Gruyter \& Co., Berlin 1957, s. 278-322. 
Hartmann N., Myśl filozoficzna i jej historia, przeł. J. Garewicz, w: N. Hartmann, Myśl filozoficzna i jej historia. Systematyczna autoprezentacja, Wydawnictwo Comer, Toruń 1994.

Hartmann N., Zur Methode der Philosophiegeschichte, in: idem, Kleinere Schriften, Bd. 3: Vom Neukantianismus zur Ontologie, Walter de Gruyter \& Co., Berlin 1958, s. 1-22.

Hegel G.W.F., Wykłady z historii filozofii, t. 1, przeł. Ś.F. Nowicki, przejrzał A. Węgrzecki, Wydawnictwo Naukowe PWN, Warszawa 1994.

Hegel G.W.F., Zasady filozofii prawa, przeł. A. Landman, Zasady filozofii prawa Warszawa 1969.

Heidegger M., Gesamtausgabe, Bd. 27: Einleitung in die Philosophie, hrsg. von O. Saame, I. Saame-Speidel, Vittorio Klostermann, Frankfurt am Main 1996.

Jaspers K., Einführung in die Philosophie. Zwölf Radiovorträge, 28. Aufl., Piper Verlag, München-Zürich 1989.

Jaspers K., Nachwort (1955) zu meiner "Philosophie” (1931), in: idem, Philosophie, Bd. 1: Philosophische Weltorientierung, 3. Aufl., Verlag von Julius Springer, Berlin-Göttingen-Heidelberg 1956.

Jaspers K., Wprowadzenie do filozofii. Dwanaście odczytów radiowych, przeł. A. Wołkowicz, Siedmioróg, Wrocław 1995.

Kroner R., Von Kant bis Hegel, Bd.1: Von der Vernunftkritik zur Naturphilosophie, Verlag von J.C.B. Mohr (Paul Siebeck), Tübingen 1921.

Natorp P., Philosophie. Ihr Problem und ihre Probleme. Einführung in den kritischen Idealismus, 2. Aufl., Vandenhoeck \& Ruprecht, Göttingen 1918.

Natorp P., Philosophische Propedeutik (Allgemeine Einleitung in die Philosophie und Anfangsgründe der Logik, Ethik und Psychologie) in Leitsätzen zu akademischen Vorlesungen, 2. Aufl., N.G. Elwert'sche Verlagsbuchhandlung, Marburg 1905.

Natorp P., Philosophische Systematik. Mit der Gedenkrede zum 100. Geburtstag am 24.1.1954 von Hans-Georg Gadamer, Einleitung und textkritische Anmerkungen von H. Knittermeyer, Felix Meiner Verlag, Hamburg 1958.

Natorp P., Selbstdarstellung, in: Philosophie der Gegenwart in Selbstdarstellungen, hrsg. von R. Schmidt, Bd. 1, 2. Aufl., Verlag von Felix Meiner, Leipzig 1923, s. 161-190.

Noras A.J., Debata Trendelenburg - Fischer. Problem obiektywności Kantowskich form zmysłowości, „Przegląd Filozoficzny - Nowa Seria” 2013, R. 22, nr 1, s. 267-297.

Noras A.J., Historia neokantyzmu, Wydawnictwo Uniwersytetu Śląskiego, Katowice 2012.

Ricoeur P., Zadanie hermeneutyki, w: idem, Jezyk, tekst, interpretacja. Wybór pism, przeł. P. Graff, K. Rosner, oprac. K. Rosner, Państwowy Instytut Wydawniczy, Warszawa 1989.

Rohm S., Objektiver Geist und Ontologie der Sprache. Nicolai Hartmann und Hans-Georg Gadamer, LIT Verlag, Berlin 2008.

Windelband W., Geschichte der Philosophie, Akademische Verlagsbuchhandlung von J.C.B. Mohr (Paul Siebeck), Freiburg i.B. 1892. 
Windelband W., Präludien. Aufsätze und Reden zur Einführung in die Philosophie, Bd. 1. 4. Aufl., Verlag von J.C.B. Mohr (Paul Siebeck), Tübingen 1911.

Winter E., Ethik und Rechtswissenschaft. Eine historisch-systematische Untersuchung zur Ethik-Konzeption des Marburger Neukantianismus im Werke Hermann Cohens, Duncker \& Humblot, Berlin 1980. 